\title{
PRESSURES AND STATUS OF SEAGRASS ECOSYSTEM IN THE COASTAL AREAS OF NORTH BINTAN, INDONESIA
}

\author{
Ita $_{\text {Karlina }}{ }^{*}$, Fery Kurniawan ${ }^{2}$ and Fadhliyah Idris ${ }^{1}$
}

${ }^{1}$ Marine Science Departement,Faculty of Marine Science and Fisheries, Raja Ali Haji Maritime University, Jl. PoliteknikSenggarang 29111 Tanjungpinang,

${ }^{2}$ Center for Coastal and Marine Resources Studies, Bogor Agricultural University, Indonesia

\begin{abstract}
This study investigates the status and anthropogenic pressures on seagrass ecosystem. Urbanization and tourism in the coastal areas of Bintan, Indonesia were increasing in the recent years. They have become new pressures to intertidal ecosystem and habitats, particularly seagrass ecosystem. Seagrass meadows are the important ecosystem and habitats in Bintan region. They provide a wide range of ecosystem services, including for small-scale fisheries and have being Dugongs (Dugong dugon) habitats for food. Currently, the sea grass status is less healthy or damaged with 11 species. The anthropogenic disturbance processes have affected the spatial distribution, percent coverage, biodiversity, and community structure of sea grass. Moreover, several species are hard to find. Directly, sea grass meadows are impacted by introduced coastal development (i.e. settlement area, tourism accommodation, port, etc.), land-based pollution, reclamation, boating traffic, dredging activities and tourism activities. Sea grass conservation area and marine spatial planning based on the land- and seascape connectivity is important for conservation efforts and sustainable management of sea grass.
\end{abstract}

\section{Introduction}

Understanding of the relations between sea grass ecosystem as ecological systems and social system is developing. Sea grass ecosystem provide significant number of function and benefit for human and nature (multiple ecosystem services) as a coupled social-ecological system (SES), including recreational fishing [19], tourism[10], fisheries [2], [20], food security [3], [8], carbon storage and climate change mitigation [15], habitat function [16], conservation function, especially for dugongs (Dugong dugon) as endangered species [8], etc.

In Indonesia, sea grass beds are under widespread pressure to decline with the main threats i.e. coastal development, land reclamation, deforestation, seaweed farming, fishing, garbage dumping, oil pollution, run-off, marine culture and public awareness[18] [13], whereas in some areas, the coastal communities and traditional fisherman are actual dependent on the existence of sea grass ecosystems [18], [19], [2], [17], [7]. The destruction of the sea grass ecosystem will change the SES of coastal areas, ecological health, habitat function and human well-being[2], [19], [20], [3], [16], [8], [6]. Moreover, some other pressures that threaten the sea grass are tourism, dredging, boating activities and sedimentation [10], [9], [12]. The aim of the study is to investigate the status and anthropogenic pressures on sea grass ecosystem.

\section{Materials and methods}

\subsection{Study Area}

Urbanization and tourism in the coastal areas of Bintan, Indonesia were increasing in the recent years. They have become new pressures to intertidal ecosystem and habitats, particularly sea grass ecosystem. Sea grass meadows are the important ecosystem and habitats in Bintan region. They provide a wide range of ecosystem services, including for small-scale fisheries and have being Dugongs (Dugong dugon) habitats for food. Efforts to conserve seagrass beds once existed, but are no longer running due to dependence on project funds. 


\subsection{Pressure factors identification}

The identification of pressure factors in Bintan is done through in-depth interviews with experts. Experts were selected from academic institutions, government agencies, non-government organizations and local communities experienced at least 3 years in sea grass studies, area managers and a minimum of 10 years for local communities. In addition, the desk study is also conducted from research papers on sea grass conducted at the study site. The questions to the expert focus on the pressures on the sea grass and the recommendations needed.

\subsection{Sea grass sampling}

This study was focused at sea grass beds ecosystem in North Bintan area. There are four observation stations were set based on the level of complexity in SES and the different condition of sea grass ecosystem (Fig. 1). The process of data collection was completed systematically by using line transect method by placing quadrant 1 x $1 \mathrm{~m}$ [11].

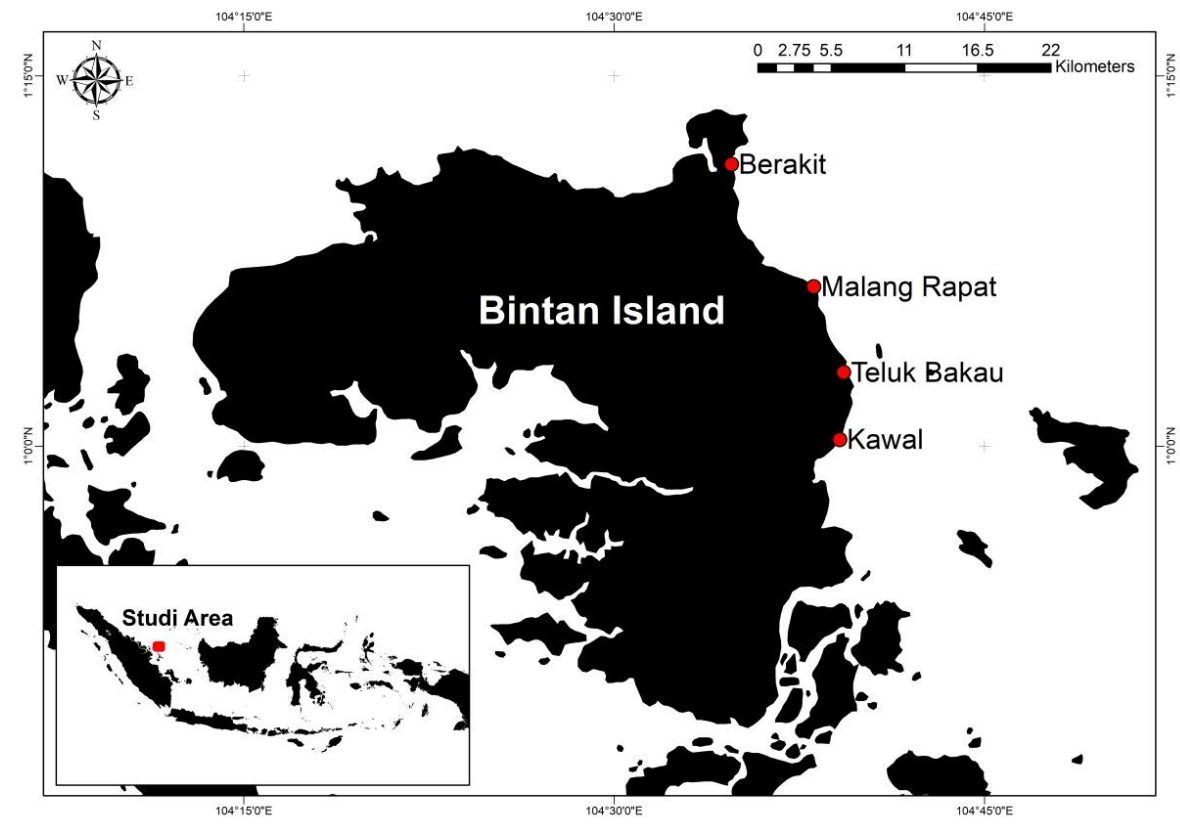

Fig 1. Study area.

\subsection{Environmental Quality}

To determine the sea grass status caused by anthropogenic, several parameters of environmental quality were analyzed, including temperature, $\mathrm{pH}$, salinity, nitrate, phosphate and substrate. The substrate sample was taken using a paralon pipe to a depth of $20 \mathrm{~cm}$. Measurements and sampling of environmental quality parameters are taken at the sea grass condition observation stations. The temperature, $\mathrm{pH}$ and salinity are measured in-situ using portable equipment, while the analysis of nitrate, phosphate and the fraction of the sediment were done in the laboratory using the standard protocol of American Public Health Association - APHA [1].

\subsection{Data analysis}

The qualitative data were analyzed descriptively, whereas descriptive statistics and one-way ANOVA were used to compare the sea grass density between the four sites. Statistics analyses were achieved with PASW Statistics 18 (Predictive Analytics Software). To obtain a quantitative measure of the sea grass structure of the community was conducted the analysis of Shannon's diversity index (H') [5], Simpson' evenness index (E) and dominance index (C) [14]. 


\section{Results and discussion}

\subsection{Pressure}

Some of the activities that are pressure factors on the sea grass ecosystem are as follows:

1. Tourism: beach and berkarang (taking shells and other biota in the sea grass ecosystem)

Beach tourism is quite popular in North Bintan. In some tourism actors' perspective, the existence of sea grasses is considered disruption the beauty of the beach and coastal tourism activities, so that many sea grasses are discarded. In addition, the tourist activities that directly interact with the sea grass to make the seagrass leaves cut. The other pressure of the tourism is the activities of berkarang, which is the activity of taking shells and marine biota in the seagrass ecosystem during low tide.

\section{Oil pollution}

The pollution of black oil or sludge oil occurs annually in the northern seasons (December-March). The waste is able to contaminate the intertidal area, including the sea grass ecosystem. Many sea grasses and association biota are covered with oil. Oil pollution is a major threat to the sea grass ecosystem in Bintan [18].

3. Illegal port

Illegal ports are traditional ports built by communities without government permission or are not included in coastal development planning. The existence of ports can increase the activity of ship traffic and waste generated from the seepage of fuel, paint and washing the ship, thus making the sea grass ecosystem disrupted and damaged.

4. Reclamation

Reclamation activities take place along Kawal beach, and in some beach areas of Bakau, Trikora and Berakit. Reclamation generally aims to support coastal development, both for resorts and hotels to provision tourism, as well as settlements. The reclamation will convert the sea grass area.

\section{Marine debris}

Marine debris usually comes in the north season, either plastic waste (plastic bottle, plastic bag, plastic pact, etc.), organic (grass, wood, etc.), other household waste. The garbage is buried on the beach and in the sea grass.

\section{Boating activities}

Boating activities can directly affect seagrass beds, either because of ship traffic or off anchors. The anchor fishing activities of the fishing and the tourist boats still have not been arranged, so it can take off any place, including in the sea grass meadow.

\section{Fisheries}

Small-scale fishermen in North Bintan do a lot of fishing activities around the sea grass ecosystem, either using nets or hand-line fishing, including the activities of berkarang (collecting shellfish). In fact, the current fishing around the sea grass has also become a recreational activity [19]. This activity is also regarded as a pressure on the ecosystem because it is not matched by good regulation and conservation efforts.

\subsection{Sea grass ecosystem status}

In Bintan region, the sea grass status in Bintan is currently less healthy or damaged [13]or with a percentage of cover ranging from 30 to $59.9 \%$ based on Decree of the Minister of Environment No. 200/2004 on Criteria of Damage Standard and Guidelines on Sea grass Status Determination [18] also report that status of sea grass in Bintan is some loss and/or degradation.

The status can also be seen from the sea grass distribution and density. Based on the observation result obtained 10 types of sea grass only, i.e. Enhallusacoroides (Ea), Thallasiahempricii (Th), Cymodocearotundata (Cr), C. serrulata (Cs), Syringodiumisoetifolium ( $\mathrm{Si}$ ), Hallodulleunivervis $(\mathrm{Hu}), \mathrm{H}$. pinovolia (Hp), Thalassodendroncilliatum $(\mathrm{Tc})$, Hallophilaovalis (Ho) and $\mathrm{H}$. spinulosa (Hs). In fact, previous observations mentioned that the type of sea grass in Bintan reached 11 species. Furthermore, not all species are found in every observation location; only in Berakit found 10 species of sea grass, whereas in Malang Rapat there are 9 species, 8 species in TelukBakau and 4 species in Kawal (Table 1). It shows that Kawal, TelukBakau and Malang Rapat have a moderate diversity index $(1.45,2.75$ and 2.95), and only Berakit has a high diversity index value (3.76) (Table 2). 
Table 1. Seagrass distribution in the coastal area of north Bintan.

\begin{tabular}{rlcccc}
\hline \multicolumn{1}{c}{ No. } & \multicolumn{1}{c}{ Species } & Kawal & TelukBakau & Malang Rapat & Berakit \\
\hline 1 & Enhallusacoroides $(\mathrm{Ea})$ & + & + & + & + \\
\hline 2 & Thallasiahempricii $(\mathrm{Th})$ & + & + & + & + \\
\hline 3 & Cymodocearotundata $(\mathrm{Cr})$ & + & + & + & + \\
\hline 4 & C. serrulata $(\mathrm{Cs})$ & + & + & + & + \\
\hline 5 & Syringodiumisoetifolium $(\mathrm{Si})$ & - & + & + & + \\
\hline 6 & Hallodulleunivervis $(\mathrm{Hu})$ & - & + & + & + \\
\hline 7 & H. pinovolia $(\mathrm{Hp})$ & - & - & + & + \\
\hline 8 & Thalassodendroncilliatum $(\mathrm{Tc})$ & - & + & + & + \\
\hline 9 & Hallophilaovalis $(\mathrm{Ho})$ & - & + & - & + \\
\hline 10 & H. spinulosa $(\mathrm{Hs})$ & - & - & 9 & 10 \\
\hline Total & & 4 & 8 & +
\end{tabular}

+: present; -: absent.

Table 2.Seagrass density in the coastal area of north Bintan.

\begin{tabular}{|c|c|c|c|c|c|c|c|c|c|c|c|c|c|}
\hline \multirow{2}{*}{ Locations } & \multicolumn{10}{|c|}{ Seagrass density (range per $\mathrm{m}^{2}$ ) } & \multirow{2}{*}{$\mathrm{H}^{\prime}$} & \multirow{2}{*}{$\mathrm{E}$} & \multirow{2}{*}{$\mathrm{C}$} \\
\hline & $E a$ & $T h$ & $\mathrm{Cr}$ & Cs & $S i$ & $H u$ & $T c$ & Ho & $H p$ & $H s$ & & & \\
\hline Kawal & $58-80$ & $24-30$ & $0-20$ & $0-15$ & 0 & 0 & 0 & 0 & 0 & 0 & 1.45 & 0.27 & 0.52 \\
\hline TelukBakau & $20-25$ & $24-30$ & $30-40$ & $43-55$ & $30-36$ & $0-55$ & $2-8$ & $9-11$ & 0 & 0 & 2.75 & 0.85 & 0.17 \\
\hline $\begin{array}{l}\text { Malang } \\
\text { Rapat }\end{array}$ & $10-30$ & $14-21$ & $24-40$ & $16-29$ & $0-24$ & $0-8$ & $0-7$ & $0-26$ & $0-21$ & 0 & 2.94 & 0.87 & 0.17 \\
\hline Berakit & $40-55$ & $0-38$ & $15-21$ & $19-26$ & $14-29$ & $9-27$ & $2-8$ & $0-28$ & $16-28$ & $0-4$ & 3.76 & 1.17 & 0.14 \\
\hline Mean & 40 & 23 & 24 & 25 & 17 & 12 & 3 & 9 & 8 & 1 & - & - & - \\
\hline $\begin{array}{l}\text { Std. } \\
\text { Deviation }\end{array}$ & 23.22 & 11.58 & 13.25 & 17.25 & 15.11 & 19.54 & 3.66 & 11.82 & 11.67 & 1.41 & - & - & - \\
\hline P-value & 0.04 & 0.85 & 0.17 & 0.04 & 0.12 & 0.57 & 0.58 & 0.73 & 0.73 & 0.48 & - & - & - \\
\hline
\end{tabular}

Ea:Enhallusacoroides; Th: Thallasiahempricii; $\quad \mathrm{Cr}$ : $\quad$ Cymodocearotundata; $\quad$ Cs: $\quad$ C. $\quad$ serrulata; $\quad$ Si: Syringodiumisoetifolium; $\mathrm{Hu}$ : Hallodulleunivervis; $\mathrm{Hp}$ : H. pinovolia; Tc: Thalassodendroncilliatum; Ho: Hallophilaovalis; and Hs: H. spinulosa. Significant p-values are in bold $(p<0.05)$.

Additionally, the highest average density value is only 40 ind. $\mathrm{m} 2-1$ with the type of EA, although the other types average only from 1 to 23 ind. $\mathrm{m} 2-1$ (Table 2). The value indicates the condition of sea grass ecosystem is very rare and unhealthy because decreasing sea grass density negatively influences associated fauna [16], [18]. The analysis statistics demonstrated that the location showed a significant difference $(\mathrm{p}<0.05)$ on the seagrass density of species of Ea and Cs, however other species are not significant difference (Table 2). That is, the density and distribution of the species are uneven across all observation locations. The evenness index values show the low category in Kawal area $(0.27)$ and high category in TelukBakau, Malang and Barakit area $(0.85,0.87,1.17)$. This condition also greatly affects the composition of the species. Generally, the dominating species is EA, followed by Cr, Cs and Th (Fig. 2). The highest dominance occurred in Kawal area (0.52), while in TelukBakau, Malang Rapat and Berakit are relatively low (Table 2). The differences caused by several factors referred substrate, coastal depth, waters condition and coastal activities or the factors of pressure to seagrass meadow.

The environmental conditions at North Bintan are less appropriate for seagrass ecosystems. Generally, seagrasses grew on substrate of sand and muddy sand category. Based on a few parameter of environmental quality, the parameter of temperature (31-32 $\left.{ }^{\circ} \mathrm{C}\right), \mathrm{pH}(6-6.9)$ and salinity (29.30-32.33 \%o) are out of range of marine water quality standard, therefore nitrate and phosphate parameters are exceeded the standard ranged from 5.88 to $9.00 \mathrm{mg} \mathrm{1-1}$ and 6.00 to 7.00 mg 1-1, respectively (Table 3). Pollution sources affecting water quality are estimated to come from settlements and tourism accommodation, including hotels and resorts. BPS Bintan Regency (2017) recorded that residents in the areas of Berakit, Kawal, TelukBakau and Malang Rapat reached 11.452 people, while tourism accommodation has reached 42 units. Consequently, the result shows that anthropogenic factors are the main supplier of the pollution on environmental. 


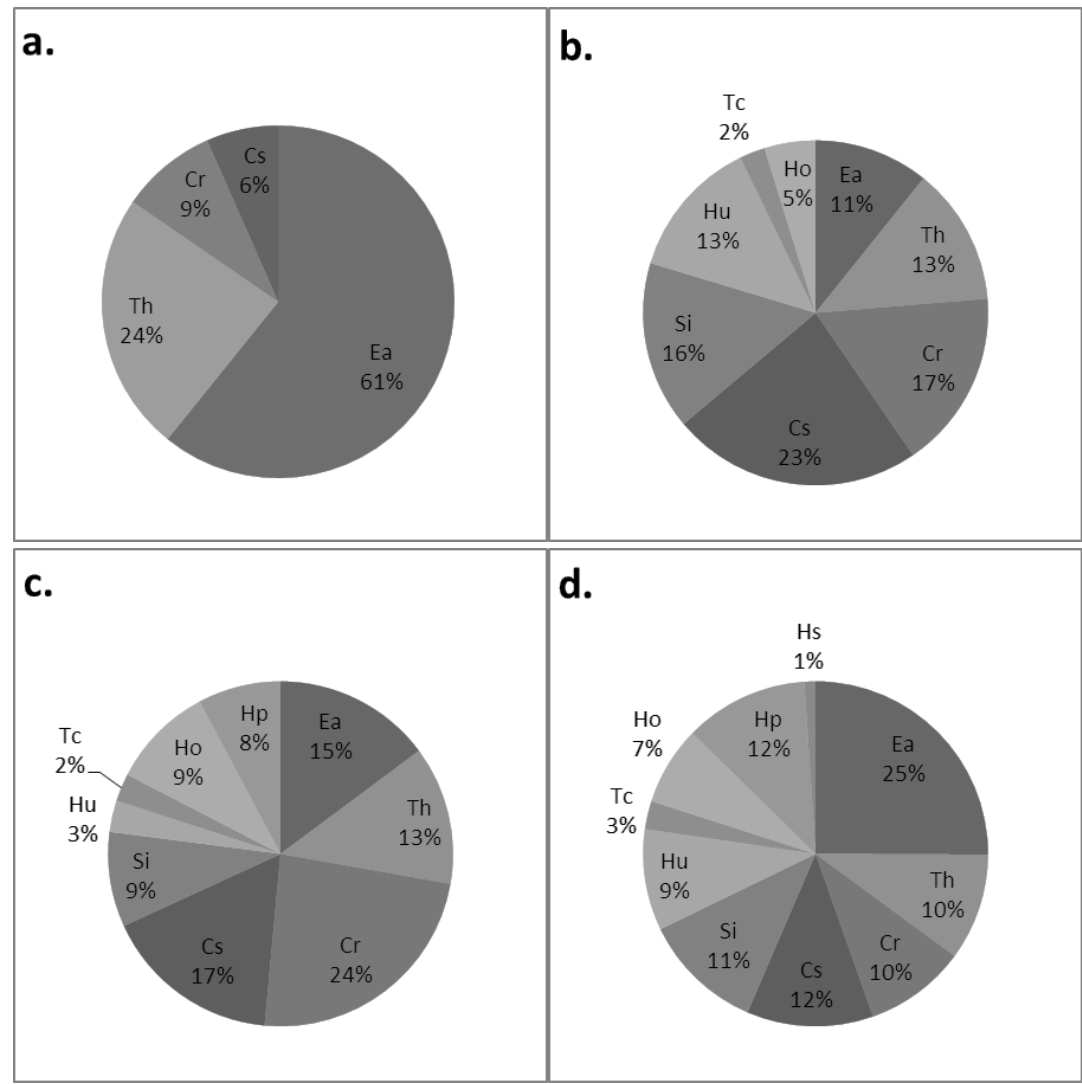

Fig 2. The composition of seagrass species at each station. a. Kawal; b. TelukBakau; c. Malang Rapat; and d.Berakit.

Table 3. Range of environmental condition at seagrass ecosystem in the coastal area of north Bintan.

\begin{tabular}{|c|c|c|}
\hline Environmental quality parameters & Range & Quality standard ${ }^{\mathrm{a}}$ \\
\hline Temperature $\left({ }^{\circ} \mathrm{C}\right)$ & $31-32$ & $28-30$ \\
\hline $\mathrm{pH}$ & $6.0-6.9$ & $7-8.5$ \\
\hline Salinity (\%o) & $29.30-32.33$ & $33-34$ \\
\hline Nitrate $(\mathrm{mg} / \mathrm{l})$ & $5.88-9.00$ & 0.008 \\
\hline Phosphate (mg/l) & $6.00-7.00$ & 0.015 \\
\hline Substrate & ly sand & - \\
\hline
\end{tabular}

\section{Conclusions}

In Bintan, seagrass meadows provide multiple ecosystem services, namely provisioning services, regulating services, and cultural services. Averagely, the economic value of seagrass for recreational fishing is estimated at around IDR $351,179.56$ ha-1 year-1 [19]. Seagrass ecosystem areas have supported the fisherman income from fish catch, with total revenue IDR 202,124 day-1 or $12 \mathrm{~kg}$ day-1 in Malang Rapat Village and IDR 193,151 day-1 or $13.8 \mathrm{~kg}$ day-1 in Berakit village [2]. However, there are many pressures that threaten the existence of seagrass ecosystem, i.e. tourism, oil 
pollution, illegal port, reclamation, marine debris, boating activities and fisheries. For that, conservation efforts are a crucial need to protect the function of seagrass ecosystem services. Specifically, sea grass conservation area and marine spatial planning based on the land- and seascape connectivity is important for sustainable management of seagrass, including blue carbon strategies. Adaptive co-management is well-defined to build the processes of decision making and public awareness.

\section{References}

1. [APHA] American Public Health Association. American Public Health Association (APHA) (2012)

2. Arkham MN, Adrianto L, Wardiatno Y. JurnalIlmudanTeknologiKelautanTropis7(2) (2016)

3. Baker S, Paddock J, Smith AM, Unsworth RKF, Cullen-Unsworth LC, Hertler H. Ecosystem Services 11:1221.(2015)

4. [BPS KabupatenBintan]. Center of Indonesia-Statistic-Statistics of Bintan Regency. 2017Brower JE, Zar JH. Field and Laboratory Methods for General Ecology. Dubuque, Iowa (US): Brown Company Publihsers (1998)

5. Campagne CS, Salles JM, Boissery P, Deter J..Mar Pollut Bull 97(1-2):391-400 (2015)

6. Cullen-Unsworth LC, Jones BL, Seary R, Newman R, Unsworth RKF. Mar Pollut Bull(2017)

7. Cullen-Unsworth LC, Nordlund LM, Paddock J, Baker S, McKenzie LJ, Unsworth RK.. Mar Pollut Bull 83(2):387-97 (2014)

8. Cuttriss AK, Prince JB, Castley JG. Aquatic Botany 108:41-47(2013)

9. Daby D. Environmental Pollution 125(3):313-324 (2003)

10. English S, Wilkinson C, Baker V. Townsville (AU): Australian Institute of Marine Science(1997)

11. Freeman AS, Short FT, Isnain I, Razak FA, Coles RG. Biological Conservation 141(12):2993-3005(2008)

12. Hernawan UE, Sjafrie NDM, Supriyadi IH, Suyarso, Iswari MY, Anggraini K, Rahmat. Jakarta (ID): PuslitOseanografi - LIPI (2017)

13. Krebs CJ. New York (US): Harper Collins Publishers (1989)

14. Mazarrasa I, Samper-Villarreal J, Serrano O, Lavery PS, Lovelock CE, Marba N, Duarte CM, Cortes J. Mar Pollut Bull (2018)

15. McCloskey RM, Unsworth RK. PeerJ 3:e1053 (2015)

16. Sjafrie NDM, Adrianto L, Damar A, Boer M. Environment, Development and Sustainability 20(2):865881.(2017)

17. Unsworth RKF, Ambo-Rappe R, Jones BL, La Nafie YA, Irawan A, Hernawan UE, Moore AM, CullenUnsworth LC. Sci Total Environ 634:279-286 (2018)

18. Wahyudin Y, Kusumastanto T, Adrianto L, Wardiatno Y. Ecological Economics 148:22-35 (2018)

19. Wawo M. IOP Conference Series: Earth and Environmental Science 89:012023 (2017) 